\title{
The Irony of Fishermen Life in Bontang Islands, East Kalimantan, Indonesia
}

\author{
Sudharto P. Hadi ${ }^{1, *}$, Sri Suryoko ${ }^{1}$, Bulan Prabawani ${ }^{1}$ \\ ${ }^{1}$ Department of Business Administration, Faculty of Social and Political Science, Diponegoro University, Jl. Prof. Soedarto, SH \\ Tembalang, Semarang, Central Java,Indonesia
}

\begin{abstract}
Bontang Bay, East Kalimantan is strategically located and rich in marine resources. However, people live at the islands of Gusung and Malahing are generally poor. This paper observes the socio-economic condition of fishermen at the two small islands and their relation with industries. The data collection techniques consist of physical observation, informal interview, and document review. The gathered data is analysed qualitatively. Fishermen at Gusung and Malahing are adversely affected by the impacts of climate change. In addition they are trapped by collectors (middle men) for financing operational cost of fishing and supporting their life during draught season. Their area are vulnerable of being impacted by industries' activities such as oil spill, smoke stake and odor. It is required for industries located at the area to help alleviate fishermen poverty by initiating innovative CSR for creating self-reliance community.
\end{abstract}

Keywords: Poor Fishermen, Climate Change, Middlemen Trap, Industries, Innovative CSR

\section{Introduction}

Bontang known as a city on the eastern coast of the Island of Borneo, Indonesia. The environment of Bontang city are fully by rich marine resources. It show Bontang's people job as fishermen. But, in the other hand industrilisation start to developed in this City. This can affect Bontang environment.

Fishermen is considered the poorest of the poor. They are currently facing uncertain season caused by climate change. During the draught season comes, they could not go fishing and consequently do not have any income. The weed culture as a second job has a problem with disease. To support their live and to finance their fishing operation they borrow money from collector (middleman), buying the fish from fishermen and selling them to other places. However, the fishermen are obliged to sell their caught fish to the collectors with the price determined by the collectors. Ironically, their settlements are surrounded by various industries such as fertilizer factory, natural gas liquefied, Kaltim Mandiri Energy, Methanol Factories and others. This paper outlines the socio-economic condition of fishermen at the islands of Gusung and Malahing, Bontang Bay and their relation with industries surrounding their settlement.

\section{Methodology}

The type of research is descriptive analysis and its scope includes the socio-economic of fishermen, the factors causing fishermen poverty, the relation between fishermen and the industries and proposed recommendation to alleviate the poverty. The data *Corresponding author: sudhartophadi@yahoo.co.id collection techniques include physical observation, informal interview with fishermen and persons in charge of CSR of Fertilizer Company. The gathered data is analyzed qualitatively.

A research done by Shaffril et al found that the impacts of climate change in the form of rainfall and increased temperature adversely affect fishermen's productivity[1]. In Malaysia during the north-east monsoon, fishermen catch drop until $20 \%$. In addition, climate change causes reduction of fishing days, damage to fishermen's productive and non-productive assets, exposure to health problems, and decreased food supply. The measure to deal with these problems include providing knowledge about climate change, involving fishermen in planning based on their needs, abilities and interests and improving their access to credit helping their efforts to adapt and expedite recovery processes.

Senapati and Gupta note that sea level rise triggers heavy rainfall, floods and cyclones, damages the coastal property and infrastructure, decreases the availability of fish, fish migration and loss of fishing boat and nets[2]. These phenomena place a serious burden on the coastal communities. Senapati and Gupta found that these fishermen are also often exploited by middlemen while marketing fish ${ }^{2}$. The vulnerability of fishing communities in Mumbai is further increased due to pollution of coastal waters. Miñarro et al found the patron-client relationship indirectly causes a worse environmental impact by encouraging higher exploitation rates[3]. This market-driven fishing behavior may threaten the long-term usability of their marine resources, risking a poverty trap. Shaffril et al note that fishermen who are dependent on nature, experience many challenges caused by a climate change. Risks reduction, social relationships, climate change knowledge, alternative skills, involvement in planning 
and access to credit are among the alternative solutions for social adaptation ${ }^{1}$.

\section{Discussion}

People live at the islands Gusung and Malahing originally came from Mamuju, West Sulawesi known as Mandar ethnic and widely recognized as excellent fishermen. They are socially tied by the same original of place, religion and occupation. Their main job is fishermen with catching instrument is fishing rod and caught fish are white fish, tongkol kakap, kerapu, bawis. The regular price of white fish is IDR $45000,-$ / $\mathrm{kg}$, kakap and kerapu IDR $25000,-/ \mathrm{kg}$. During the catching season, the minimum income from fishing is IDR 50 000,- and the most is Rp 200.000,- Operational cost for gasoline reaches IDR 45000 ,-. The caught fish are sold to local collectors (middlemen) at the island. The price of canoe reach IDR 2 - 4 million, the canoe engine IDR 2, 500.000 - IDR 4 million. The side job is culturing a sea weed. The price of dried sea weed is IDR 6000 ,- each $\mathrm{kg}$. Sea weed is being harvested in 40 days. With the capital of IDR 5 million, they earn IDR 1.400.000 each harvest. They sell the sea weed to a collector in Bontang City. During the uncertain season, most fishermen's income is only IDR 50.000,- per day and is not enough to cover the operational cost. Seaweed cultured is also in a bad condition because of disease. In addition to the loan from collector, they get the one from Fertilizer company. In a such condition, they could not return a loan. They are vulnerable because of the uncertain income and trapped with collectors (middlemen).

The crucial problems encountered by local residents are the lack of clean water. They have to buy a clean water from the nearest villages like Tanjung Limau or Lok Tuan for Gusung and Bontang City for Malahing for IDR 300.000,- to IDR 400.000,- per month per household. The second crucial problem is school boat for school children to take them from their islands to Bontang City. They are currently share their own boat to commute to Bontang. Most fishermen in Gusung and Malahing are at below poverty line. Few of them who have a capital are economically better and acting as collectors (middleman). The average education attainment is primary school and there are few of them did not even finish their primary school. From their perspective, their main job is fishermen. If they or their children could not continue their studies they finally back as fishermen.

Gusung island is a cluster of land resulted from the rest of reclamation done by Fertilizer Company in

\section{References}

1. H. A. M. Shaffril, A.A. Samah, and J.L. D'Silva, "Climate Change: Social Adaptation Strategies for Fishermen", “Adapting Towards Climate Change Impacts: Strategies For Small-Scale Fishermen in Malaysia”, Marine Policy 81 pp. 256-261, pp. 196-20 (2017).
1979. This island is occupied by only one neighborhood association (RT) consisting of 83 households ${ }^{4]}$. People in Gusung are adversely affected by odor caused by a startup process of fertilizer company occasionally occur in the morning around 7:00. Their settlement was also affected by oil spill caused by tanker ship operating around their island. Gusung has potential of marine resources with variety of fish and for culturing seaweed.

Malahing island is part of Tanjung Laut Indah Village. In 2001, people started building settlement at the sea. There are 52 households with 215 people, 31 households are categorized as poor families[4]. Women have processed sea-weed as variety of snacks and their products have been marketed and promoted to Bontang City and other places of East Kalimantan with the assistance from Fertilizer Company

\section{Conclusion}

Fishermen in the islands of Gusung and Malahing are currently facing the impact of climate change adversely affect their livelihood. In such uncertain condition, they are powerless in encountering patron-client system trapping them in poverty. These findings are parallel with previous research done by Shaffril, Senapati and Gupta, and Pelras. Based on these findings, the following recommendations are proposed:

a. In addition to providing a loan as working capital, it is required for industries to provide facilitation and extension specifically for sea weed culture. The facilitation is required to deal with sea-weed disease and to process sea-weed to be variety of snacks by involving women.

b. To deal with the trap of collectors, with the assistance of Fertilizer Company and other industries, it is necessary to build a mini plant for processing fish, so that there will be a value added enjoyed by fishermen. This initiative requires involvement of collectors to jointly manage the mini plant

c. Based on need assessment done, it is necessary for Fertilizer Company and other industries to provide needed infrastructures such as providing a clean water by refining seawater or channeling a clean water from Guntung to Gusung or from Tanjung Indah Village to Malahing. Other needed infrastructures include additional class rooms for grade 5 and 6 of Primary School in Malahing, school boats to commute school children from Gusung and Malahing to Bontang City.

2. S. Senapati, and G. Vijaya, "Socio-Economic Vulnerability due to Climate Change: Deriving Indicators for Fishing Communities in Mumbai", Marine Policy 76 pp. 90-97 (2017).

3. S. Miñarro, et al., "The Role of Patron-Client Relations on The Behaviour of Artisanal Fishermen in The Spermonde Archipelago (Indonesia)", Marine Policy 69 pp. 73-83 (2016). 
4. Badan Pusat Statistik Kota Bontang, "Bontang dalam Angka" (2016).
5. C. Pelras, "Manusia Bugis (The Bugis)", Nalar and Ecole Francaise d'Extreme-Orat (EFFO), Jakarta and Paris (2006). 